\title{
한국프로농구구단의 생산성분석; $\mathrm{DEA}$ 를 중심으로 \\ 김 선 민 \\ "서울과학기술대학교 글로벌경영학과
}

\section{A Productive Analysis of Sports Organizations in Korean Basketball League; Focused on DEA \\ $\underline{\text { Seonmin } \mathrm{Kim}^{*}}$ \\ ${ }^{*}$ Dept. of Business Administration, Seoultech}

\begin{abstract}
Due to the competition between the various professional events, it is imperative for the team's management to improve efficiency by removing the inefficiencies of the professional team in order to gain a competitive edge. This study use different Data Envelopment Analysis (DEA) models to measure the efficiency of professional sport organizations. In this mathematical-analytical study, this study first reviews the related literature to analyze the input/output variables. In the end, the variables were detected and the data for this study were gathered from the Korean Basketball League (KBL).

While previous studies examine relative efficiency of Korean Professional baseball teams by using CCR model, this study fully utilize the DEA method to investigate Korean professional sports organizations' operating problem. Thus, this study propose full results of DEA analysis such as efficiency score (overall, technical, and scale efficiency), slacks in inputs and outputs of inefficient organizations, Malmquist index) As a result, this study provides not only the exact productivity information of a team and a way of improving a firm's productivity with a decision maker.
\end{abstract}

Keywords : Data Envelopment Analysis, Performance Evaluation, Sports Organizations, Korean Basketball League

1. 서 론

2010년 체육백서에 따르면 국내스포츠산업의 규모는 33조 4천억 원에 달할 정도로 국내스포츠산업은 비약적으로 발전 하고 있다.[1] 스포츠산업의 규모를 $\mathrm{GDP}$ 기준으로 살펴보면, 국내스포츠산업의 상대적 규모는 세계 1 위인 미국과 비슷한 $3 \%$ 대이며, 국내스포츠산업의 절대적 규모는 앞으로 경제 규 모가 커짐에 따라 점차 증가할 것으로 예상된다.

스포츠산업은 스포츠 및 그와 관련된 재화나 서비스를 생
산. 유통시켜 부가가치를 창출하는 산업으로 정의된다. 특히, 프로스포츠 산업은 국민들의 레저 생활과 연계되어 그 발전 가능성이 매우 높은 유망산업으로 인식되고 있다. 현재 국내 프로스포츠 가운데 프로야구가 가장 먼저 1982년 출범하였고, 프로축구가 1983년, 프로농구가 1997년, 프로배구가 2005년에 출범하였다[2]. 그러나 국내스포츠산업 중 프로스포츠 구단 운영은 다양한 종목간의 경쟁으로 인하여, 아직까지 대기업 의 지원이 없이 자체적으로 수익을 내는 구단은 적은 편이다.

† Corresponding Author: Seon-Min Kim ,Dept. of Business Administration, Seoultech,

172, Gongneung 2-dong, Nowon-gu, Seoul, Korea

M • P: 010-2735-6497, E-mail: skim@snut.ac.kr

Received April 20, 2013; Revision Received June 18, 2013; Accepted June 18, 2013. 
따라서 프로스포츠 구단의 경영수지 개선을 위해서 는 프로구단들의 비효율성을 파악하여 이를 제거함으 로써, 효율성을 높이는 것이 경쟁력을 확보하는데 중요 하다. 실무적으로 구단의 효율적 운영을 파악하기 위한 방법으로는 다양한 벤치마킹 기법이 -비교대상 구단의 성과와의 효율성 비교를 측정- 사용될 수 있다.

자료포괄분석 (Data Envelopment Analysis; 이하 DEA 로 표기하기로 함)은 최근 가장 널리 사용되는 벤치마킹 기법이다. DEA 기법은 여러 투입-산출 요인을 이용하여 상대적인 효율성을 측정하는 비모수적인 방법으로 가장 큰 장점은 투입과 산출 간의 함수적 관계(production function)의 가정을 할 필요가 없다는 점이다.

프로구단의 성과와 투입 요소들 간의 관계를 측정하 기 위해 DEA 기법을 사용하여 분석한 여러 연구가 이 미 발표되었다. 프로축구 구단의 효율성 관련 연구로는 이영한[3]의 연구가 있는데, 그는 자료포락분석을 이용 하여 2003년 시즌 단일기간을 대상으로 투입변수로 총 연봉(선수 연봉 + 코칭스탭 연봉 + 프런트 직원의 연 봉)을, 산출변수로는 시즌승률과 시즌평균관중을 토대 로 규모의 수익불변을 가정하는 $\mathrm{CCR}$ 효율성만을 분석 하였다. 프로야구의 경우, 강호정[2]은 2006년부터 2009 년까지 최근 4개년도 자료를 이용하고, 투입변수로 선 수단 운영비를, 산출변수로는 시즌 승점과 매출액을 사 용하여 규모의 수익불변을 가정하는 $\mathrm{CCR}$ 효율성을 분 석과 맘퀴스트지수를 이용한 생산성 변화를 측정하였 다. 원동연 등[6]은 DEA 모형과 Malmquist Index를 이용하여 2006년부터 2008년까지의 한국 프로야구 구 단들의 상대적 효율성과 생산성 변화를 측정하였으나, 의사결정단위가 상대적으로 적은 문제점을 보여주고 있다. 특히, 한국프로농구구단을 대상으로 효율성을 분 석한 연구는 이영훈[5]의 생산함수 추정에 의한 분석이 유일하다.

본 연구는 부족한 국내 프로스포츠 구단의 생산성분 석 연구를 확장한다는 차원에서 다음과 같은 연구 질문 에 대한 답을 찾고자 하였다: 한국의 대표적인 겨울 프 로스포츠 구단인 프로농구 구단의 상대적 효율성과 생 산성 변화의 측정을 통해 효율적으로 구단을 운영하는 팀은 얼마나 되는가? 특히, 비효율적으로 판명된 프로 구단의 경우, 생산성 향상을 위해 경영진에게 어떠한 개선 방안을 제시할 수 있는가? 본 연구에서는 $\mathrm{DEA}$ 분석을 통해 팀별 상대적 효율성 및 생산성 추이를 분 석하여, 위의 연구 질문에 대한 답을 하고자 하였다.

본 연구의 구성은 다음과 같다. 2장에서는 프로구단 의 생산성 분석에 사용된 DEA 분석 방법을 설명하고, 3 장에서는 $\mathrm{DEA}$ 분석을 적용하기 위한 기초자료 및 한 국프로농구 구단의 효율성 분석을 제시하고, 4 장에서는
$\mathrm{DEA}$ 분석을 통해 나타난 결과에 기반을 둔 본 연구의 결론과 향후 연구방향을 제시한다.

\section{2. $\mathrm{DEA}$ 분석}

$\mathrm{DEA}$ 모형은 영리기관의 효율성 평가방법(비율분석, 생산성 지수법, 함수적접근법 등)에 있어서의 문제점을 보완한 비모수적인 방법이다. 이 방법은 현재 공공기관 인 정부, 비영리기업 등의 다양한 조직의 성과평가에 적용되고 있다. DEA 분석방법은 Charnes, Cooper, Rhodes[4]에 의해 개발된 CCR 모형과 그 후 기술적 효율성만을 고려한 $\mathrm{BCC}$ 모형 등이 추가로 개발되었다. $\mathrm{DEA}$ 분석은 다수의 투입요소와 산출요소에 관한 비율 모형으로서 Ferrell의 효율성 개념을 새로이 해석하여 개발된 선형계획모형이다. 또한 DEA 모형은 산출지향 과 투입지향별로 달리 해석되기도 한다. 산출지향 모형 은 투입물을 고정시킨 상태에서 산출물을 얼마만큼 최 적의 상태로 결합시키는가에 초점을 두는 모형(투입에 영향을 주지 않는 범위에서 산출물을 확대)이며, 투입 지향모형은 산출물을 고정시킨 상태에서 투입물의 최 적 배분에 초점을 두는 모형(투입물을 감소시키는 형태 로 나타남) 이다.

$\mathrm{CCR}$ 모형은 단일의 효율성점수를 제공하며, $\mathrm{CCR}$ 모 형을 목적함수와 제약조건의 식으로 표현하면 아래의 식(1)과 같이 나타낼 수 있다. 한다.

$$
\max h=\frac{\sum_{r=1}^{t} u_{r} y_{r j o}}{\sum_{i=1}^{m} V_{i} x_{i o}}
$$

s.t.

$$
\begin{aligned}
& \frac{\sum_{r=1}^{t} u_{r} y_{r j}}{\sum_{i=1}^{m} v_{i} x_{i j}} \leq 1 \\
& u_{r}, \quad V_{i} \geq \varepsilon, \forall r \text { and } i
\end{aligned}
$$

여기서, $\mathrm{t}$ 는 효율성을 측정하고자 하는 대상 의사결 정단위(DMU)의 산출요소의 수를, $\mathrm{m}$ 은 투입요소의 수 를 나타내며, $x_{i j}=\mathrm{j}$ 단위로 부터의 입력 $\mathrm{i}$ 의 양, $y_{i j}=$ $\mathrm{j}$ 단위로 부터의 산출 $\mathrm{r}$ 의 양을 나타낸다. 또한 $u_{r}$ 은 대상 $\mathrm{DMU}(\mathrm{r})$ 의 산출 $\mathrm{r}$ 의 가중치, $v_{i}=$ 입력 $\mathrm{i}$ 에 주어진 가중치를 의미한다. 여기서는 $\epsilon$ 은 양의 작은 수를 의미 한다.

이론적으로, $\mathrm{CCR}$ 모형은 $\mathrm{DMU}$ 별 투입요소 및 산출 
요소가 주어진 상태에서 DMU별로 효율성을 최대화할 수 있는 투입 및 산출 요소들의 가중치를 계산하여, 효 율성 점수를 제공한다. 기본적으로 비율모형이기 때문 에 효율적인 $\mathrm{DMU}$ 들은 ' 1 '의 효율성 점수를, 비효율적 인 $\mathrm{DMU}$ 들은 "1"보다 작은 효율성 점수를 갖게 된다. 또한 $\mathrm{DEA}$ 에 의한 효율성 점수 결과는 상대적으로 비 효율적인 $\mathrm{DMU}$ 들에 대하여 효율성 개선을 위한 참조 집단을 제공한다. 이에 따라 비효율적인 $\mathrm{DMU}$ 은 참조 집단이 제공하는 가중치의 결합을 통해서 비효율성의 원인을 개선할 수 있게 된다.

$\mathrm{CCR}$ 모형은 불변규모수익(constant return to scale) 의 가정 하에 각 $\mathrm{DMU}$ 의 효율성을 평가하는 방법이지 만, 현실적으로 모든 조직들이 최적의 규모에서 운영되 고 있다고 가정하는 것은 한계가 있다. 이러한 한계를 극복하기 위한 방안으로 Bank et al. (1984)은 규모수 익이 변화하는 상황에서 주로 순수기술효율성을 파악 하기 위한 모형을 제시하였으며, $\mathrm{BCC}$ 모형의 일반식은 다음과 같은 식(2)로 나타낼 수 있다.

$$
\max h=\frac{\sum_{r=1}^{t} u_{r} y_{r j o}-u_{0}}{\sum_{i=1}^{m} V_{i} X_{i o}}
$$

s.t.

$$
\begin{aligned}
& \frac{\sum_{r=1}^{t} u_{r} y_{r j}-u_{0}}{\sum_{i=1}^{m} V_{i} X_{i j}} \leq 1 \\
& u_{r}, \quad V_{i} \geq_{\varepsilon}, \forall r \text { and } i
\end{aligned}
$$

이모형의 목적함수와 $\mathrm{CCR}$ 모형의 목적함수를 비교 해보면, $\mathrm{BCC}$ 모형에 인자가 추가되어 있음을 알 수 있 는데 이는 규모에 대한 지표 (indicator of return to scale)로서 규모의 경제를 파악하는 용도로 사용된다. 그러나 의 값이 측정단위에 따라 그 크기가 변동함으 로, 규모의 경제에 대한 절대적인 값을 제공하는 것은 아니며, 단지 규모의 경제 여부만을 알려준다. 특히, $\mathrm{BCC}$ 모형은 $\mathrm{CCR}$ 모형에 제약요소가 추가된 형태이므로, $\mathrm{BCC}$ 모형을 통한 획득한 비효율적인 $\mathrm{DMU}$ 의 효율성점 수는 $\mathrm{CCR}$ 모형을 통한 획득한 비효율적인 $\mathrm{DMU}$ 의 효 율성점수보다 크다.

$\mathrm{CCR}$ 모형을 이용한 분석결과와 $\mathrm{BCC}$ 모형을 이용한 분 석결과를 비교하면, 주어진 생산 활동 규모 하에서 규모 효율성(scale efficiency)을 알 수 있다. CCR 모형을 통해 획득한 효율성점수는 불변규모수익을 가정한 상태에서 구 한 값이기에 규모효율성과 순수 기술효율성을 구분하지 못하는 단점을 갖고 있다. 그리고 $\mathrm{BCC}$ 모형을 통해 획득
한 효율성점수는 가변수익규모를 가정한 상태에서 구한 값이기에 이 효율성 점수는 순수기술효율성을 나타낸다. 따라서 두 모형의 효율성점수가 모두 1 이라면 가장 효율 적인 규모와 기술의 크기에서 $\mathrm{DMU}$ 이 운영되는 것이다. $\mathrm{CCR}$ 모형의 효율성 점수와 $\mathrm{BCC}$ 모형의 효율성 점수를 상호 비교함으로써 규모효율성 점수를 계산할 수 있다. 따라서 이를 활용하여, DMU의 비효율성이 기술적 측면 에서 발생하는 것인지, 혹은 규모에 의해 발생하는 것인 지를 파악하여 효율성 개선의 방향을 파악할 수 있다.

\section{3. 한국프로농구구단의 효율성 분석}

\section{1 자료의 수집}

본 연구의 분석기간은 2009년부터 2011년까지의 3개 시즌을 대상으로 하며, 3 개 시즌 동안 자료입수가 가능 한 프로농구 구단을 대상으로 하였다. 이들 10 구단에 대한 자료는 한구프로농구 홈페이지를 통하여 획득하 였으며, 자료처리는 Frontier Analyst 3.0을 이용하였다. $\mathrm{DEA}$ 를 사용하여, 프로농구 구단의 효율성을 측정하기 위해서는, 효율성의 평가에 중요하며 충분히 인과관계 가 있다고 판단되는 투입요소와 산출요소의 선정이 필 요하다. 그 이유는 투입요소 및 산출요소의 선택에 따 라 DMU의 효율성이 크게 달라질 수 있기 때문이다[4]. 본 연구에서는 선행연구를 토대로, 투입요소로는 선수 단 연봉총액, 고액연봉선수의 비율을 선정하였으며, 산 출요소로는 승률, 경기당 관중수를 선정하였다. 특히 고액 연봉 선수의 비율은 각 년도별 평균 연봉의 2 배 에 해당하는 선수의 수의 연봉의 합을 총 구단 선수 연봉액으로 나누어 계산하였다. 예를 들어, 프로농구의 경우에는 연봉 2 억 원 이상인 선수의 연봉의 합을 총 구단 선수 연봉액으로 나누어 계산하였다.

\section{2 주요변수의 기초통계량}

본 연구에서 고려하고 있는 10 개 한국프로농구 구단 들의 투입요소와 산출요소를 연도별로 정리한 것이 $<$ Table 1>에 제시되어 있다. 
$<$ Table $1>$ Yearly data of Input and output variables in DMUs

\begin{tabular}{|c|c|c|c|c|c|}
\hline \multirow{2}{*}{ 구단 } & \multicolumn{2}{|c|}{ 투입요소 } & \multicolumn{2}{|c|}{ 산출요소 } & \multirow{2}{*}{ 연도 } \\
\hline & 총선수단연봉 & 고액선수비율 & 승률 & 평균 광중 수 & \\
\hline 원주동부 & 167100 & 0.5446 & 0.611 & 3239 & \multirow{10}{*}{2009} \\
\hline 울산 모비스 & 124400 & 0.6029 & 0.648 & 3519 & \\
\hline 서울 삼성 & 156700 & 0.7211 & 0.556 & 6453 & \\
\hline 서울 $\mathrm{SK}$ & 180800 & 0.5144 & 0.444 & 6505 & \\
\hline 창원 $\mathrm{LG}$ & 140300 & 0.4027 & 0.537 & 5542 & \\
\hline 고양 오리온스 & 149600 & 0.5281 & 0.333 & 3633 & \\
\hline 인천 전자랜드 & 150500 & 0.5648 & 0.537 & 3706 & \\
\hline 전주 $\mathrm{KCC}$ & 148500 & 0.4108 & 0.574 & 5650 & \\
\hline 안양 $\mathrm{KGC}$ & 119000 & 0.6134 & 0.537 & 3111 & \\
\hline 부산 $\mathrm{KT}$ & 149100 & 0.4024 & 0.222 & 2365 & \\
\hline 원주동부 & 179600 & 0.540 & 0.611 & 2649 & \multirow{10}{*}{2010} \\
\hline 울산 모비스 & 143900 & 0.418 & 0.741 & 4837 & \\
\hline 서울 삼성 & 176100 & 0.613 & 0.481 & 4004 & \\
\hline 서울 SK & 180000 & 0.511 & 0.296 & 5583 & \\
\hline 창원 $\mathrm{LG}$ & 168000 & 0.429 & 0.63 & 4923 & \\
\hline 고양 오리온스 & 96600 & 0.197 & 0.278 & 2188 & \\
\hline 인천 전자랜드 & 180000 & 0.642 & 0.278 & 3706 & \\
\hline 전주 $\mathrm{KCC}$ & 180000 & 0.508 & 0.648 & 5593 & \\
\hline 안양 $\mathrm{KGC}$ & 135700 & 0.538 & 0.296 & 2378 & \\
\hline 부산 $\mathrm{KT}$ & 165600 & 0.483 & 0.741 & 5604 & \\
\hline 원주동부 & 176200 & 0.653 & 0.574 & 3529 & \multirow{10}{*}{2011} \\
\hline 울산 모비스 & 139000 & 0.540 & 0.370 & 2843 & \\
\hline 서울 삼성 & 163000 & 0.571 & 0.500 & 4628 & \\
\hline 서울 SK & 189000 & 0.651 & 0.370 & 5655 & \\
\hline 창원 $\mathrm{LG}$ & 146500 & 0.362 & 0.519 & 4762 & \\
\hline 고양 오리온스 & 111700 & 0.269 & 0.278 & 1755 & \\
\hline 인천 전자랜드 & 182600 & 0.436 & 0.704 & 5288 & \\
\hline 전주 $\mathrm{KCC}$ & 188500 & 0.658 & 0.630 & 5465 & \\
\hline 안양 $\mathrm{KGC}$ & 131500 & 0.471 & 0.296 & 2343 & \\
\hline 부산 $\mathrm{KT}$ & 182750 & 0.454 & 0.759 & 5784 & \\
\hline
\end{tabular}

\section{3 한국프로농구 구단의 효율성 분석}

본 연구에서 한국프로농구 구단 10 개의 $\mathrm{DMU}$ 에 대 하여 2009, 2010, 2011년도 자료를 바탕으로 CCR모형 (불변규모수익을 전제로 하는 투입지향 $\mathrm{CCR}$ 모형과 $\mathrm{BCC}$ 모형 (가변규모수익을 전제로 하는 투입지향 $\mathrm{BCC}$ 모형)을 적용하여 효율성 분석을 실시하였다. 본 연구 에서 투입지향 DEA 모형을 적용한 이유는 본 연구의 목적이 결과물보다는 투입의 효율성을 통한 학술연구
성과의 극대화에 있기 때문이다.

먼저, 규모수익 불변을 전제로 하는 $\mathrm{CCR}$ 분석결과, 효 율적으로 판명된 구단 (효율성 지수의 값이 $100 \%$ 이상 인 것임)은 2009년에는 울산 모비스, 서울삼성, 창원 $\mathrm{LG}$, 전주 $\mathrm{KCC}$ 등 4개 구단, 2010년에는 울산 모비스 와 부산 $\mathrm{KT}$ 2개 구단, 그리고 2011년에는 창원 LG와 부산 KT 2개 구단으로 밝혀졌다. 특히, 2009년도와 2010년도에는 울산모비스가, 2011년도에는 부산 KT의 효율성지수가 가장 높게 나타나 있음을 알 수 있다. 
$<$ Table 2> Efficiency results of DMUs using CCR models

\begin{tabular}{|c|c|c|c|c|c|c|}
\hline & $\begin{array}{c}2009 \\
\text { 효율성지수 }\end{array}$ & $\begin{array}{c}\text { 참조집합 } \\
\text { 빈도수 }\end{array}$ & $\begin{array}{c}2010 \\
\text { 효율성지수 }\end{array}$ & $\begin{array}{c}\text { 참조집합 } \\
\text { 빈도수 }\end{array}$ & $\begin{array}{c}2011 \\
\text { 효율성지수 }\end{array}$ & $\begin{array}{c}\text { 참조집합 } \\
\text { 빈도수 }\end{array}$ \\
\hline 원주동부 & $87.40 \%$ & 0 & $66.07 \%$ & 0 & $78.44 \%$ & 0 \\
\hline 울산 모비스 & $117.61 \%$ & 3 & $115.48 \%$ & 1 & $64.55 \%$ & 0 \\
\hline 서울 삼성 & $104.25 \%$ & 1 & $67.19 \%$ & 0 & $87.36 \%$ & 0 \\
\hline 서울 $\mathrm{SK}$ & $91.89 \%$ & 0 & $94.15 \%$ & 0 & $92.05 \%$ & 0 \\
\hline 창원 $\mathrm{LG}$ & $103.35 \%$ & 4 & $99.01 \%$ & 0 & $103.43 \%$ & 5 \\
\hline $\begin{array}{c}\text { 고양 } \\
\text { 오리온스 }\end{array}$ & $60.50 \%$ & 0 & $95.88 \%$ & 0 & $61.98 \%$ & 0 \\
\hline $\begin{array}{c}\text { 인천 } \\
\text { 전자랜드 }\end{array}$ & $79.25 \%$ & 0 & $60.84 \%$ & 0 & $96.69 \%$ & 0 \\
\hline 전주 $\mathrm{KCC}$ & $104.79 \%$ & 2 & $94.84 \%$ & 0 & $89.87 \%$ & 0 \\
\hline 안양 $\mathrm{KGC}$ & $88.95 \%$ & 0 & $51.78 \%$ & 0 & $55.98 \%$ & 0 \\
\hline 부산 $\mathrm{KT}$ & $42.70 \%$ & 0 & $100.69 \%$ & 7 & $108.35 \%$ & 6 \\
\hline
\end{tabular}

$\mathrm{CCR}$ 모형을 사용한 효율성과는 달리, $\mathrm{BCC}$ 모형을 사용한 효율성은 규모의 수익 가변을 가정하여 계산한 순수 기술 효율성을 의미한다. 즉, 규모의 수익가변성 을 가정하기 때문에 효율적인 프로구단의 수가 $\mathrm{CCR}$ 효율성 모형보다 늘어나게 된다. 2009년도에는 울산 모
비스, 서울삼성, 서울 $\mathrm{SK}$, 창원 $\mathrm{LG}$, 전주 $\mathrm{KCC}$, 안양 $\mathrm{KGC}$, 부산 $\mathrm{KT}$ 등 7 개 구단 , 2010년에는 울산 모비스, 고양 오리온스, 부산 KT 등 3개 구단, 그리고 2011년 도에는 창원 $\mathrm{LG}$ 와 고양 오리온스, 부산 $\mathrm{KT}$ 등 3 개 구 단이 효율적으로 나타났다.

$<$ Table 3> Efficiency results of DMUs using BCC models

\begin{tabular}{|c|c|c|c|c|c|c|}
\hline & $\begin{array}{c}2009 \\
\text { 효율성지수 }\end{array}$ & $\begin{array}{c}\text { 참조집합 } \\
\text { 빈도수 }\end{array}$ & $\begin{array}{c}2010 \\
\text { 효율성지수 }\end{array}$ & $\begin{array}{c}\text { 참조집합 } \\
\text { 빈도수 }\end{array}$ & $\begin{array}{c}2011 \\
\text { 효율성지수 }\end{array}$ & $\begin{array}{c}\text { 참조집합 } \\
\text { 빈도수 }\end{array}$ \\
\hline 원주동부 & $93.07 \%$ & $72.73 \%$ & & $87.86 \%$ & \\
\hline 울산 모비스 & $\mathrm{big}$ & 1 & $115.48 \%$ & 7 & $89.92 \%$ & \\
\hline 서울 삼성 & $\mathrm{big}$ & 0 & $73.28 \%$ & & $88.93 \%$ & \\
\hline 서울 $\mathrm{SK}$ & $\mathrm{big}$ & 0 & $94.16 \%$ & & $94.28 \%$ & \\
\hline 창원 $\mathrm{LG}$ & $104.95 \%$ & 2 & $99.30 \%$ & & $112.59 \%$ & 6 \\
\hline 고양 오리온스 & $89.18 \%$ & & $212.70 \%$ & 4 & $134.70 \%$ & 4 \\
\hline 인천 전자랜드 & $87.19 \%$ & & $68.73 \%$ & & $99.37 \%$ & \\
\hline 전주 $\mathrm{KCC}$ & $157.30 \%$ & 1 & $94.84 \%$ & & $90.95 \%$ & \\
\hline 안양 $\mathrm{KGC}$ & $104.54 \%$ & 2 & $73.69 \%$ & & $90.12 \%$ & \\
\hline 부산 $\mathrm{KT}$ & $100.07 \%$ & 0 & $\mathrm{big}$ & 3 & $\mathrm{big}$ & 4 \\
\hline
\end{tabular}


규모효율성은 $\mathrm{CCR}$ 효율성(기술효율성 값)을 $\mathrm{BCC}$ 효 율성(순수기술효율성) 값으로 나누어 계산할 수 있다. 프로농구구단별 규모효율성의 값은 <Table $4>$ 에서 제 시하는 바와 같이 나타났다. 규모 효율적인 구단으로는 2009년도에 울산 모비스, 서울 삼성 등 2개 구단이, 2010년에는 울산 모비스, 서울 SK, 부산 KT 등 3개 구단이, 2011년에는 창원 $\mathrm{LG}$, 부산 $\mathrm{KT}$ 등 2개 구단으 로 나타났다.

$<$ Table $4>$ Scale efficiency of DMUs

\begin{tabular}{|c|c|c|c|}
\hline & $\begin{array}{c}2009 \\
\text { 효율성지수 }\end{array}$ & $\begin{array}{c}2010 \\
\text { 효율성지수 }\end{array}$ & $\begin{array}{c}2011 \\
\text { 효율성지수 }\end{array}$ \\
\hline 원주동부 & 0.939 & 0.908 & 0.893 \\
\hline 울산 모비스 & 1.000 & 1.000 & 0.718 \\
\hline 서울 삼성 & 1.000 & 0.917 & 0.982 \\
\hline 서울 SK & 0.919 & 1.000 & 0.976 \\
\hline 창원 LG & 0.985 & 0.997 & 1.000 \\
\hline 고양 오리온스 & 0.678 & 0.959 & 0.620 \\
\hline 인천 전자랜드 & 0.909 & 0.885 & 0.973 \\
\hline 전주 KCC & 0.666 & 1.000 & 0.988 \\
\hline 안양 KGC & 0.851 & 0.703 & 0.621 \\
\hline 부산 KT & 0.427 & 1.000 & 1.000 \\
\hline
\end{tabular}

\section{4 한국프로농구 구단의 생산성 분석}

\subsection{1 맘퀴스트 생산성 분석}

맘퀴스트 생산성 분석 (Malmquist Productivity Analysis)은 주어진 투입요소를 이용하여 최대로 생산 할 수 있는 산출물의 거리함수를 추정하여 서로 다른 시점의 투입 및 산출조합의 관찰치를 이용하여 생산성 지수를 계산하고, 시간의 변동에 따라 개별 $\mathrm{DMU}$ 의 생 산효율성(Productive efficiency)이 어떻게 변동되는지 혹은 시간의 변동에 따른 $\mathrm{DMU}$ 간 생산효율성 변동에 어떤 차이가 나타내는지를 분석하는 기법이다. 이때, Malmquist Index가 1보다 크면 생산성 향상, Malmquist Index가 1보다 작으면 생산성 감소를 의미 한다.

<Table 5>는 프로구단들의 2009-2011년간의 생산성 변화 결과를 Malmquist Index를 사용하여 나타내고 있 다. 2009 2010 기간의 생산성 변화를 살펴보면, 울산 모비스와 고양 오리온스는 생산성 향상, 나머지 구단은 생산성 감소가 나타났음을 알 수 있으며, 2010 2011 기간의 생산성 변화를 살펴보면, 서울 삼성, 창원 $\mathrm{LG}$, 안양 $\mathrm{KGC}$ 등이 생산성 향상, 부산 $\mathrm{KT}$ 는 생산성 불변, 나머지 구단들은 생산성 감소가 나타났음을 알 수 있다.
$<$ Table 5> Results of Malmquist productivity analysis

\begin{tabular}{|c|c|c|c|}
\hline \multirow{2}{*}{ 팀명 } & \multicolumn{3}{|c|}{ Malmquist Index } \\
\cline { 2 - 4 } & $2009-2010$ & $2010-2011$ & $\begin{array}{c}\text { 평균 } \\
\text { 생산성지수 }\end{array}$ \\
\hline 원주동부 & 0.9490 & 0.9575 & 0.9532 \\
\hline 울산 모비스 & 1.1343 & 0.5609 & 0.7976 \\
\hline 서울 삼성 & 0.5938 & 1.2403 & 0.8582 \\
\hline 서울 SK & 0.8637 & 0.9518 & 0.9067 \\
\hline 창원 LG & 0.9370 & 1.1146 & 1.0219 \\
\hline 고양 오리온스 & 1.4946 & 0.6595 & 0.9928 \\
\hline 인천 전자랜드 & 0.7338 & 1.6197 & 1.0902 \\
\hline 전주 KCC & 0.8590 & 0.9177 & 0.8879 \\
\hline 안양 KGC & 0.5758 & 1.0181 & 0.7657 \\
\hline 부산 KT & 2.2848 & 1.0091 & 1.5184 \\
\hline 기하평균 & 0.9565 & 0.9666 & 0.9615 \\
\hline
\end{tabular}

\subsection{2 총요소생산성 추정 및 동질성 분석}

<Table 6>은 2009-2011년의 분석기간 동안 MPI, 즉 총요소생산성 변화의 추정치를 보여준다. 이 기간 동안 $\mathrm{MPI}$ 의 기하평균이 0.9615 로 추정되어 평균적으로 $4 \%$ 정도의 생산성 하락이 있는 것으로 분석되었다. TECI 는 0.9913으로 추정되어, 프로농구단 운영에 있어 투입 과 산출의 기술적인 결합을 통한 효율성의 하락이 거 의 없는 것으로 나타났으며, 이를 다시 순순한 투입 대 비 산출의 기술효율성변화 $(\mathrm{PECI}=0.9855)$ 와 규모에 따른 효율성변화 $(\mathrm{SECI}=1.006)$ 로 구분하여 살펴보면, 규모보다는 기술효율성의 향상이 필요함을 알 수 있다. 기술진보를 나타내는 TCI는 0.97로 나타나 일정한 투 입으로부터 최대의 산출을 얻어내는 조직의 능력에서 $3 \%$ 의 하락을 보여주고 있다. 이는 총요소생산성 하락 의 원인이 운영의 비효율성과 경영기법의 퇴보에 의해 발생하였음을 알 수 있다.

$<$ Table 6> Average MPI changes for all teams in time series

\begin{tabular}{|c|c|c|c|c|c|}
\hline \multicolumn{5}{|c|}{ 시계열 평균 생산성 지수 } \\
\hline 시계열 & TECI & TCI & PECI & SECI & MPI \\
\hline T2 & 0.9792 & 0.9768 & 0.8953 & 1.0938 & 0.9565 \\
\hline T3 & 1.0035 & 0.9632 & 1.0847 & 0.9252 & 0.9666 \\
\hline 기하평균 & 0.9913 & 0.97 & 0.9855 & 1.006 & 0.9615 \\
\hline
\end{tabular}


분석기간을 세분하여, 2009년 대비 2010년 생산성과 2010년 대비 2011년 생산성을 비교하면, 다음과 같은 분석결과를 얻을 수 있다. 첫째, 두 기간의 $\mathrm{MPI}$ 가 각각 0.9565, 9666으로 2010-2011년의 생산성이 약간 상승하 였지만, 프로농구단의 생산성에는 큰 변화없이 점진적 으로 생산성이 증가한 것으로 나타났다. 둘째, 총요소 생산성의 변화의 원인을 발견하기 위해, 세분하여 살펴 보면, TECI는 각각 0.9792 와 1.0035로 추정되어 약 $3 \%$ 정도 상승하였고, TCI는 각각 0.9768과 0.9632로 추정 되어, 거의 변화가 없으며, $\mathrm{PECI}$ 는 0.8953과 1.0847 로 추정되어 2009-2010년에는 약 $11 \%$ 하락하였다가, 2010-2011년에는 8\% 정도 상승하였고, SECI는 1.0938 과 0.9252로 추정되어 2009-2010년에는 약 9\% 상승하 였다가, 2010-2011년에는 8\% 정도 상승하였다. 이러한 결과는 비록, 총요소생산성의 변화는 크게 나타나지 않 았지만, TECI의 구성성분인 PECI와 SECI는 서로 상반 된 움직임을 보이고 있음을 알 수 있었다.

$<$ Table $7>$ MPI estimates for each team in year 2009-2010

\begin{tabular}{|c|c|c|c|c|c|}
\hline DMU & TECI & TCI & PECI & SECI & MPI \\
\hline 원주동부 & 0.7559 & 1.2555 & 0.7815 & 0.9674 & 0.949 \\
\hline $\begin{array}{c}\text { 울산 } \\
\text { 모비스 }\end{array}$ & 1 & 1.1343 & 1 & 1 & 1.1343 \\
\hline $\begin{array}{l}\text { 서울 } \\
\text { 삼성 }\end{array}$ & 0.6719 & 0.8837 & 0.7328 & 0.9169 & 0.5938 \\
\hline 서울 SK & 1.0246 & 0.843 & 0.9416 & 1.0881 & 0.8637 \\
\hline 창원 $\mathrm{LG}$ & 0.9901 & 0.9464 & 0.993 & 0.9971 & 0.937 \\
\hline $\begin{array}{c}\text { 고양 } \\
\text { 오리온스 }\end{array}$ & 1.5848 & 0.9431 & 1.1213 & 1.4133 & 1.4946 \\
\hline $\begin{array}{c}\text { 인천 } \\
\text { 전자랜드 }\end{array}$ & 0.7677 & 0.9558 & 0.7883 & 0.9739 & 0.7338 \\
\hline $\begin{array}{l}\text { 전주 } \\
\mathrm{KCC}\end{array}$ & 0.9484 & 0.9057 & 0.9484 & 1 & 0.859 \\
\hline $\begin{array}{l}\text { 안양 } \\
\mathrm{KGC}\end{array}$ & 0.5821 & 0.9892 & 0.7369 & 0.79 & 0.5758 \\
\hline 부산 $\mathrm{KT}$ & 2.3419 & 0.9756 & 1 & 2.3419 & 2.2848 \\
\hline 기하평균 & 0.9792 & 0.9768 & 0.8953 & 1.0938 & 0.9565 \\
\hline
\end{tabular}

$<$ Table 8> MPI estimates for each team in year 2010-2011

\begin{tabular}{|c|c|c|c|c|c|}
\hline $\mathrm{DMU}$ & TECI & TCI & PECI & SECI & MPI \\
\hline 원주동부 & $\begin{array}{c}1.187 \\
2\end{array}$ & 0.8065 & 1.208 & 0.9828 & 0.9575 \\
\hline $\begin{array}{c}\text { 울산 } \\
\text { 모비스 }\end{array}$ & $\begin{array}{c}0.645 \\
5\end{array}$ & 0.869 & 0.8992 & 0.7179 & 0.5609 \\
\hline $\begin{array}{l}\text { 서울 } \\
\text { 삼성 }\end{array}$ & $\begin{array}{c}1.300 \\
2 \\
\end{array}$ & 0.9539 & 1.2136 & 1.0714 & 1.2403 \\
\hline 서울 SK & $\begin{array}{c}0.977 \\
7\end{array}$ & 0.9735 & 1.0013 & 0.9765 & 0.9518 \\
\hline 창원 $\mathrm{LG}$ & 1.01 & 1036 & 1.007 & 1.0029 & 1.1146 \\
\hline $\begin{array}{c}\text { 고양 } \\
\text { 오리온스 }\end{array}$ & $\begin{array}{c}0.646 \\
4\end{array}$ & 1.0202 & 1 & 0.6464 & 0.6595 \\
\hline $\begin{array}{c}\text { 인천 } \\
\text { 전자랜드 }\end{array}$ & $\begin{array}{c}1.589 \\
3\end{array}$ & 1.0191 & 1.4458 & 1.0992 & 1.6197 \\
\hline $\begin{array}{l}\text { 전주 } \\
\mathrm{KCC}\end{array}$ & $\begin{array}{c}0.947 \\
6\end{array}$ & 0.9684 & 0.959 & 0.9881 & 0.9177 \\
\hline $\begin{array}{l}\text { 안양 } \\
\mathrm{KGC}\end{array}$ & $\begin{array}{c}1.081 \\
1\end{array}$ & 0.9417 & 1.223 & 0.884 & 1.0181 \\
\hline $\begin{array}{l}\text { 부산 } \\
\mathrm{KT}\end{array}$ & 1 & 1.0091 & 1 & 1 & 1.0091 \\
\hline 기하평균 & $\begin{array}{c}1.003 \\
5\end{array}$ & 0.9632 & 1.0847 & 0.9252 & 0.9666 \\
\hline
\end{tabular}

$<$ Table 9> average MPI estimates for each teams in years 2009-2011

\begin{tabular}{|c|c|c|c|c|c|}
\hline DMU & TECI & TCI & PECI & SECI & MPI \\
\hline $\begin{array}{c}\text { 원주동부 } \\
\text { 울산 } \\
\text { 모비스 }\end{array}$ & 0.9473 & 1.0063 & 0.9716 & 0.9751 & 0.9532 \\
\hline 서울 삼성 & 0.9347 & 0.9181 & 0.943 & 0.9911 & 0.8582 \\
\hline 서울 $\mathrm{SK}$ & 1.0009 & 0.9059 & 0.971 & 1.0308 & 0.9067 \\
\hline 창원 LG & 1 & 1.022 & 1 & 1 & 1.0219 \\
\hline $\begin{array}{c}\text { 고양 } \\
\text { 오리온스 }\end{array}$ & 1.0121 & 0.9809 & 1.0589 & 0.9558 & 0.9928 \\
\hline $\begin{array}{c}\text { 인천 } \\
\text { 전자랜드 }\end{array}$ & 1.1046 & 0.9869 & 1.0676 & 1.0347 & 1.0902 \\
\hline 전주 KCC & 0.948 & 0.9365 & 0.9537 & 0.994 & 0.8879 \\
\hline 안양 $\mathrm{KGC}$ & 0.7933 & 0.9652 & 0.9493 & 0.8357 & 0.7657 \\
\hline 부산 $\mathrm{KT}$ & 1.5303 & 0.9922 & 1 & 1.5303 & 1.5184 \\
\hline 기하평균 & 0.9913 & 0.97 & 0.9854 & 1.006 & 0.9615 \\
\hline
\end{tabular}




\section{4. 결론 및 시사점}

본 연구는 한국프로스포츠 구단의 효율성을 파악하 기 위하여, 겨울 프로스포츠로 인기 있는 한국프로농구 10개 구단을 대상으로, 2009 2011 기간 동안의 생산성 변화와 구단들의 상대적 효율성을 측정하였다. 본 연구 의 결과는 다음과 같다.

첫째, 규모의 수익불변을 가정하는 $\mathrm{CCR}$ 분석을 실시 한 결과, 전반적으로 효율적으로 판명된 구단보다는 비 효율적으로 판명된 구단의 수가 훨씬 많이 나타났다.

둘째, 규모의 수익가변을 가정한 $\mathrm{BCC}$ 모형을 통해 분 석한 경우에는 2009년에는 효율적인 구단이 7개로 비효 율적으로 판명된 3개 구단보다 많았지만, 2010년도부터 는 비효율적으로 판명된 구단이 훨씬 많았다. 이러한 결 과는 투입측면의 과도 투입, 산출 측면의 과소 산출이 발생에 기인한 것이기 때문에, 스포츠 구단들이 경영효 율화를 위한 노력에 많은 노력을 기울여야 할 것이다.

셋째, 규모효율성 역시 2009년에는 2개, 2010년에 는4개 구단으로 증가하였으며, 2011년에는 다시 2개 로 감소하였다.

넷째, 생산성 변화 결과를 살펴보면, 전반적으로 2009 2011 기간 동안의 생산성 지수가 1 보다 작기 때문에 한국 프로농구 구간들의 생산성이 전반적으로 하락하고 있음을 알 수 있었으며, 창원 $\mathrm{LG}$, 인천 전자랜드, 부산 $\mathrm{KT}$ 등이 생산성이 평균적으로 향상되고 있음을 알 수 있었다.

본 연구는 한국 프로스포츠 구단의 상대적 효율성 분석 및 생산성 변화를 종합적으로 살펴봄으로써, 국내 프로스포츠 산업의 효율성 향상을 위한 기초적인 경영 통찰력을 제공할 수 있다는 점에서 그 의의를 지닌다 고 할 수 있다.

\section{5. 참고 문헌}

[1] Korean Ministry of culture, sports and tourism, Sports White paper, 2010.

[2] Lee, Y.H. (2005), Measuring Efficiency of Korean Professional Sport Teams by Data Envelope Analysis, Master thesis, Seoul National University

[3] Kang, H.J. (2010), "Productivity Change and Relative Efficiency of Professional Sport Teams," Journal of the Korea contents association, Vol. 10, no. 10, 456-463.

[4] Charnes, A., W.W. Cooper and E. Rhodes, 1978. Measuring the efficiency of decision-making units. European Journal of Operations Research, 2: 429-444.

[5] Lee, Y.H (2000), "Analysis of Efficiency in Korea basketball league," Industrial Organization research, Vol. 8, No. 2,85-113.

[6] Won, D-Y, Kang, HJ., Hwang, S-H (2012)

"Productivity change and Relative efficiency of Korean professional baseball teams," Journal of the Korea contents association, Vol. 12, no. 8, $330-342$.

$$
\text { 저 자 소 개 }
$$

김 선 민

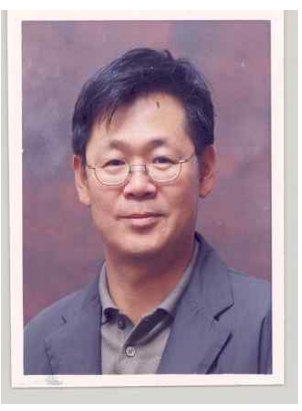

현재 서울과학기술대학교 글로벌 글로벌경영학과 교수로 재직 중이 다. 연세대학교 상경대학 경제학 과를 졸업하고, University of California, Irvine에서 경영학석사, University of Georgia에서 경영학 박사를 취득하였다. 아울러, 미국공 인 생산 및 재고관리사 (Certified Produc tion and Inventory Management)를 취득하였으며 골드렛 연구소의 학계공인 조나(academic JONAH)이다. 주 요 관심분야는 제약이론을 통한 창의적 문제해결 기법, 공 급체인관리, 서비스경영, 기술혁신 등이다.

주소: 서울시 노원구 공릉 2 동 172 서울과학기술대학교 글 로벌경영학과 